ÇOMÜ Uluslararası Sosyal Bilimler Dergisi 4 (2), 333-356 , 2019 COMU International Journal of Social Sciences 4 (2), 333-356, 2019

\title{
E-İhale Kapsamında Avrupa Birliği ve Türk Kamu Alımları'nda Dinamik Alım Sistemi’nin Karşılaştırmalı Analizi
}

Aysun GÜRBÜZ *

$\ddot{O} z$

İlk kez 2004 yllında düzenlenen Avrupa Birliği (AB) kamu alım direktiflerinde kendisine yer bulan elektronik ihale (e-ihale) uygulamaları, kamu alımlarının sadece kağıt ortamından elektronik ortama aktarılmasını sağlamayacak aynı zamanda kamu alımlarının daha şeffaf, objektif, rekabetçi uygulanarak usulsüzlük ve yolsuzlukların önüne geçilmesi ve küçük ve orta boy işletmelerin (KOBI)'lerin kamu alımlarına daha fazla katılımına imkan tanıyan devrim niteliğinde bir gelişme teșkil edecektir. $\mathrm{Bu}$ bağlamda 2004 yılında ilk kez düzenlenen ve 2014 yılında işleyişi sadeleştirilip basitleștirilen Dinamik Alım Sistemi de (DAS) tamamen elektronik ortamda gerçekleştirilen ve sisteme başvuru aşamasında yeterlilik kriterlerini sağlayan tüm isteklilerin alım kapsamındaki tüm kategorilere katılımına açı olan yenilikçi bir usul olarak gelecek vaad etmektedir. Bu makalenin amacı, AB'de Dinamik Alım Sistemi’nin nasıl uygulandığını incelemek ve Türk Kamu Alım Mevzuatı’na aktarılabilmesine ışı tutmaktır. Çalışma sonucunda Dinamik Alım Sistemi’nin başta çerçeve anlaşmalara kıyasla daha rekabetçi bir alım olduğu ve şayet isteklilere iyi öğretilirse birçok usulün yerini alabilme potansiyeli bulunduğu sonucuna varılmıştır.

\section{The Comparative Analyses of the Dynamic Purchasing System in the European Union and Turkish Public Procurement within the Context of E-Procurement}

\begin{abstract}
The implementation of electronic procurement (e-procurement) which was first introduced in the European Union (EU) Public Procurement Directives in 2004, will not only enable public procurement to be transferred from paper to electronic environment, but also will prevent the irregularities and corruption of public procurement through more transparent, objective, competitive implementation besides by allowing more participation of the small and medium sized enterprises (SMEs) to public procurement that can considered as a revolutionary development. In this context, the Dynamic Purchasing System (DPS) which was first enacted in 2004 and simplified in 2014, promises to be an innovative method that is open to the participation of all economic operators who meet the qualification criteria in all categories within the context of the DPS during the application stage of the system. The purpose of this article is to examine how the DPS is implemented in the EU and to shed light on its transfer to the Turkish Public Procurement Law. As a result of the study, it was concluded that DPS is a much more competitive procurement, particularly compared to the framework agreements, and it has
\end{abstract}

\footnotetext{
* Dr., Kamu İhale Kurumu, aysungurbuz7@gmail.com
} 
the potential to replace many procurement procedures if it is well taught to tenderers.

Key words: e-procurement, dynamic purchasing system, public procurement, European Union, Turkey

\section{GíRiş}

Avrupa Birliğìnde (AB) kamu alımları, AB gayrisafi milli hasılasının (GSMH) yaklaşık \%14'üne tekabül etmektedir². AB, kamu alımlarına yılda yaklaşık 2 trilyon $€$ harcamak yapmakta olup ${ }^{3}$ kamu alımları, $\mathrm{AB}$ üyesi devletlerin ekonomilerinde önemli bir ağırlık teşkil etmektedir.

Aralık 2011'de Avrupa Komisyonu 2004 yılında yürürlüğe giren mal, hizmet alımı, yapım işi ihaleleri hakkındaki 2004/18/AT sayılı Direktif ${ }^{4}$ (bundan böyle, Eski AB Klasik Kamu Alım Direktifi) ile 2004/17/AT sayılı Direktif'inin ${ }^{5}$ (bundan böyle, Eski AB Sektörler Direktifi) değiştirilmesi ve imtiyazlara (concessions) ilişsin de yeni bir düzenleme yapılması için öneride bulunmuştur. ${ }^{6} \mathrm{Bu}$ doğrultuda Avrupa Parlamentosu ve $\mathrm{AB}$ Bakanlar Konseyi tarafından 26 Şubat 2014 tarihinde 2014/24/AB sayılı Direktif ${ }^{\prime}$ (bundan böyle, Yeni AB Klasik Kamu Alım Direktifi) ve 2014/25/AB sayılı Direktif (bundan böyle, Yeni AB Sektörler Direktifi) ${ }^{8}$ kabul edilmiş ve üye devletlere bahsekonu yeni Direktifleri en geç 18 Nisan 2016 tarihine kadar ulusal hukuklarına aktarmaları için süre tanınmıştır. ${ }^{9}$ Sözkonusu yeni direktiflerdeki e-ihale konusundaki düzenlemeler için ise daha esnek bir yaklaşımla Ekim 2018’e kadar müsaade edilmiştir. ${ }^{10}$

2-European Commission, "Public Procurement", https://ec.europa.eu/growth/single-market/public-procurement_en, (15.11.2018), s.1.

3- Christopher H.Bovis, EU Public Procurement Law, Elgar European Law Yayınları, Cheltenham, 2013, s.1.

4- 31 Mart 2004 tarih, 2004/18/AT sayılı AP ve Konsey Direktifi, L 134, Official Journal of the European Union, 30.4.2004. Ayrica bkz. https://eur-lex.europa.eu/LexUriServ/LexUriServ.do?uri=OJ:L:2004:134:0114:0240:en:PDF, (21.12.2018).

5- 31 Mart 2004 tarih, 2004/17/AT sayll AP ve Konsey Direktifi, L 134, Official Journal of the European Union, 30.4.2004. Ayrica bkz. https://eur-lex.europa.eu/legal-content/EN/TXT/PDF/?uri=CELEX:32004L0017\&from=EN, (21.12.2018).

6-European Commission, "Legal Rules and Implementation", https:/ec.europa.eu/growth/single-market/public-procurement/rules-implementation_en, (15.11.2018), s.1.

7- 26 Şubat 2014 tarih, 2014/24/AB sayllı AP ve Konsey Direktifi, L 94, Official Journal of the European Union, 28.3.2014. Ayrica bkz. https://eur-lex.europa.eu/legal-content/EN/TXT/PDF/?uri=CELEX:02014L0024-201801 01\&from=EN, (20.11.2018).

8-26 Şubat 2014 tarih, 2014/25/AB sayll AP ve Konsey Direktifi, L 94, Official Journal of the European Union, 28.3.2014. Ayrica bkz. https://eur-lex.europa.eu/legal-content/EN/TXT/PDF/?uri=CELEX:02014L0025-201801 01\&from=EN, (20.11.2018).

9- European Commission, "Legal Rules and Implementation", s.1.

10- İbid. 
Elektronik ihale (e-ihale), elektronik araçlar yardımıyla özellikle internet üzerinden idareler ve istekliler arasında ihtiyacın tanımlanmasından ihalenin gerçekleştirilmesine, ödemeye ve akabinde sözleşme yönetimine alımla ilgili tüm aşamaları içeren bir süreçtir. ${ }^{11}$

$\mathrm{AB}$ elektronik alandaki gelişmeleri kamu alımları mevzuatına aktarma girişiminin startını özellikle 2004 yılında yürürlüğe giren Eski AB Klasik Kamu Alım Direktifi ve Eski AB Sektörler Direktifi ile vermiştir. AB, e-ihale ile kamu alımlarında elektronik araçlardan faydalanmanın ötesinde müteşebbislerin alım usullerine hem ihale verilmeden hem de ihale verildikten sonra daha kolay katılabileceği, idarelerin ihale usullerini daha kolay uygulayabileceği bir yapıya dönüştürebilmeyi amaçlamıştır. ${ }^{12}$ Kamu alımlarında elektronik araçlardan faydalanma, kamu alımlarının daha şeffaf ve objektif gerçekleştirilmesi, idari işlemlerin azaltılarak bürokrasinin en aza indirgenmesi, tüm taraflar için hem zaman hem de maddi tasarrufların sağlanması, küçük ve orta büyüklükteki işletmelerin (KOBİ) kamu alım süreçlerine daha fazla dahil olması, yenilikçiliğin teşvik edilmesi gibi geniş bir yelpazede katkı sağlayacaktır. ${ }^{13}$ Tüm süreçlerin elektronik ortama aktarılması, usulsüzlük ve yolsuzlukların önüne geçilerek şikayet sayılarının azaltılmasına da yardımcı olacaktır. Sözkonusu nedenlerle e-ihale, 2014 yılında düzenlenen Yeni AB Klasik Kamu Alım Direktifi ve Yeni AB Sektörler Direktifi ile getirilen değişikliklerin merkezinde yer almaktadir. $^{14}$

AB bir takvim çizelgesiyle aşama aşama e-ihaleyi Ekim 2018 tarihi itibariyle hayata geçirmiştir. Bu çerçevede Yeni AB Klasik Kamu Alım Direktifi ve Yeni AB Sektörler Direktifi'ni tüm üye devletlerin ulusal mevzuatlarına aktarmaları için 18 Nisan 2016 son tarih olarak belirlenmiş ve sözkonusu bu tarih itibariyle ihale ilanlarının elektronik ortamda yayımlanarak müteşebbislerin bunlardan bilgi sahibi olması ve ihale ilanları ile ihale dokümanlarına elektronik erişebilme imkanın sağlanması düzenlenmiştir. Ardından Nisan 2017 itibariyle merkezi satın alma kuruluşlarına, tekliflerin elektronik ortamda iletilmesi dahil, müteşebbislerle tamamen elektronik ortamda iletişimde olma zorunluluğu getirilmiştir. Bu yükümlülük, Ekim 2018 tarihi itibariyle tüm idarelere, uygulayacakları tüm alım usullerinde isteklilerden teklifleri elektronik olarak almaları ve isteklilerle tüm iletişimlerini elektronik olarak gerçekleştirme zorunluluğu olarak genişletilmiştir. ${ }^{15}$

$\mathrm{Bu}$ bağlamda her ne kadar bir alım usulü değil, bir alım aracı olarak nitelendirilmesi gereken ve 2004 yılında düzenlenen Eski AB Klasik Kamu Alım Direktifi ve Eski AB Sektörler Direktifi ile getirilen DAS da tamamen elektronik olarak gerçekleştirilen bir alım olduğu için aslında e-ihale ile en entegre olmuş uygulamaların başında gelmektedir.

11- Marcella Corsi, "E-procurement Overview", 2006, https://www.oecd.org/mena/governance/36238198.pdf, (12.12.2018), s.3.

12-European Commission, "E-procurement", https://ec.europa.eu/growth/single-market/public-procurement/e-procurement_en, (15.11.2018), s.1.

13- İbid.

14- İbid.

15- İbid. 
Sözkonusu nedenle aynı zamanda ülkemizin AB ile kamu alımlarını uyumlaştırma çabaları çerçevesinde $\mathrm{AB}$ direktiflerinin bu uygulamasını ülkemiz kamu alım mevzuatına aktarıp aynı zamanda uygulamaya geçirilebilmesi açısından da özel incelemeyi gerektirmektedir.

\section{YENI AB KAMU ALIM DİREKTIIFLERINNDE DİNAMİK ALIM SİSTEMİ}

Yeni AB Klasik Kamu Alım Direktifi ve Yeni AB Sektörler Direktifi'nde "Kapsam, Tanım ve Genel İlkelerin” düzenlendiği I. başlık altında 2. maddede düzenlenen “Tanımlar” kısmında DAS’a ilişkin bir tanıma yer verilmemiştir. Bununla birlikte Yeni AB Klasik Kamu Alım Direktifi 34. madde ${ }^{16}$ ve Yeni AB Sektörler Direktifi 52. maddede ${ }^{17}$ düzenlenen DAS’a ilişkin kurallar hem içerik olarak daha ayrıntılandırılarak netleştirilmiş ( 7 bendden 9 bende çıkarılmış) hem de sistemin işleyişine ilişkin usulde sadeleştirilmeye gidilmiştir. Bu çerçevede DAS, Yeni AB Klasik Kamu Alım Direktifi ve Yeni AB Sektörler Direktifi'nde idarelerin ihtiyaçlarını karşılamak üzere sıklıkla aldıkları ve genelde piyasada hazır halde bulunan alımlarını (mal, hizmet alımları ve yapım işi ihaleleri) tamamıyla elektronik ortamda, sisteme katılmak için başvuran ve yeterlilik kriterlerini sağlayan tüm isteklileri davet ederek $^{18}$ belli istekliler arasında ihale usulünü kullanmak suretiyle gerçekleştirdikleri ${ }^{19}$ bir alım aracı olarak tanımlanmaktadır. DAS’ın belli istekliler arasında ihale usulünden farklılaştığı husus, DAS kapsamında sisteme kabul edilecek aday sayısının kısıtlanmamasıdır. ${ }^{20}$ Belli istekliler arasında ihale usulünü temel alarak gerçekleştirilen DAS, pazarlığa müsaade etmeyen bir araçtır. ${ }^{21}$ DAS kapsamında bir alım, mal, hizmet veya yapım işi kategorilerine ayırılarak ve her bir kategori münferit sözleşme ile verilerek gerçekleştirebilir. ${ }^{22}$ Bu tür bir durumda idarenin her bir kategori için belirlediği yeterlilik kriterlerini ihale dokümanlarında belirtmesi gerekmektedir. ${ }^{23}$ Kategoriler, gerçekleştirilecek alımın özellikleri gözönünde bulundurularak objektif bir şekilde belirlenmeli ve AB Antlaşması'nın genel ilkelerine aykırı bir şekilde oluşturulmamalıdır. ${ }^{24}$

Dinamik Alım Sistemi çerçevesinde düzenlenebilecek kategorilere örnek olarak büro

16- 2014/24/AB, madde 34

17- 2014/25/AB, madde 52 .

18- 2014/24/AB, madde 34(1). Ayrica bkz. 2014/25/AB, madde 52(1).

19- 2014/24/AB, madde 34(2). Ayrica bkz. 2014/25/AB, madde 52(2).

20- Susie Smith, "Dynamic Purchasing System: Planning”, (2.6.2016), http://www.localgovernmentlawyer.co.uk/ index.php?option =com_content\&view=article\&id=27168\%3Adynamic-purchasing-systems-planning\&cati$\mathrm{d}=53$ \&Itemid=21, (15.11.2018), s.2.

21- İbid.,s.1.

22- 2014/24/AB, madde 34(1). Ayrica bkz. 2014/25/AB, madde 52(1).

23- 2014/24/AB, madde 34(2). Ayrica bkz. 2014/25/AB, madde 52(2).

24- Smith, “Dynamic Purchasing System: Planning”, s.2. 
mobilyalarına ilişkin mal alımının dört kategoriye (sandalye, sıra, toplantı masası ve diğer mobilyalar), bina tesisat yapım işinin üç kategoriye (elektrik tesisatı, yangın alarmı kurulumu ve asansör kurulumu) ve araç park hizmet alımının coğrafi olarak üç bölgeye ayrılması verilebilir. ${ }^{25}$ Burada özellikle belirtilmesi gereken husus kategori (category) ve kısım (lot) kavramlarının aynı anlama gelmediğidir. Zira Yeni AB Klasik Kamu Alım Direktifi ve Yeni AB Sektörler Direktifi çerçevesinde özellikle KOBİ’lerin kamu alımlarına katılımlarını arttırabilmek için getirilen "böl veya açıkla prensibi” uyarınca bir idare, yapacağı alımı kısımlara ayırmamışsa bunun gerekçelerini açıklamak zorundadır. ${ }^{26}$ Susie Smith'e göre DAS kapsamındaki kategoriler için bu tür bir zorunluluk bulunmamaktadır zira DAS’a katılacak müteşebbislerin belirlenmesi aşamasında idare, henüz bir ihale gerçekleştirmemektedir. İhale, DAS’ın ikinci aşamasında belli istekliler arasında ihale usulü kullanılarak gerçekleştirilmektedir. ${ }^{27}$ Ayrıca Yeni AB Klasik Kamu Alım Direktifi ve Yeni AB Sektörler Direktifi, idarenin bir isteklinin bir alımda başvurabileceği kısım sayısının sınırlandırmasına cevaz vermekteyken ${ }^{28}$ DAS kapsamında oluşturulacak kategoriler ve bir isteklinin başvurabileceği kategori sayısına ilişkin bir kısıtlama bulunmamaktadır. ${ }^{29}$ Kanaatimizce bu tür bir kısıtlama, rekabeti mümkün olduğu ölçüde arttırmak isteyen ve katılımcı sayısına ilişkin bir kısıtlama yapmayan DAS’ın ruhuna aykırı bir düzenleme olacaktır. Alımın kategorilere ayrılması, idarelere çok sayıda isteklinin bulunduğu alımlarda DAS’a katılım başvurularını değerlendirmesinde kolaylık sağlayacak bir düzenleme teşkil etmektedir. ${ }^{30}$ Kategorilere ayırma aynı zamanda KOBİlerin katılımını veya salt o alanda uzmanlaşmış isteklilerce alımın karşılanmasını da teşvik edecek bir uygulamadir. ${ }^{31}$

Dinamik Alım Sistemi’ne ilişkin bu genel bilgileri verdikten sonra DAS’ın nasıl işletildiğine değinecek olursak; DAS 2 aşamalı olarak uygulanmaktadır. Bu bağlamda ilk aşamada idare, DAS’ kullanarak alım yapılacağını belirten bir ihale ilanı (contract notice) yayımlar ${ }^{32}$ ve sözkonusu ilan veya diğer ihale dokümanlarında alımın özellikleri, DAS’ın nasıl işletileceği, kullanılacak elektronik araç ve sisteme teknik bağlantı ile ilgili düzenlemeleri belirtir. ${ }^{33}$ İdare, müteşebbislerin DAS yürürlükte olduğu sürece ihale

\footnotetext{
25- İbid.

26- The Organization for Economic Cooperation and Development (OECD), "Division of Contracts into Lots", 2016, http://www.sigmaweb.org/publications/Public-Procurement-Policy-Brief-36-200117.pdf, (15.11.2018), s.4. Ayrica bkz. 2014/24/AB, madde 46(1).

27- Smith, "Dynamic Purchasing System: Planning", s.1.

28- OECD, "Division of Contracts into Lots", s.4. Ayrica bkz. 2014/24/AB, madde 46(2).

29- Smith, "Dynamic Purchasing System: Planning", s.1.

30- İbid.

31- İbid.

32- 2014/24/AB, madde 34(2)(a). Ayrica bkz. 2014/25/AB, madde 52(2)(a).

33- 2014/24/AB, madde 34(4)(b). Ayrica bkz. 2014/25/AB, madde 52 (4)(b). 
dokümanlarına tam doğrudan erişimine imkan sağlar. ${ }^{34}$ İdare, ihale ilanında aynı zamanda DAS’ın ne kadar süre ile geçerli olacağını da belirtir. ${ }^{35}$ Yeni AB Klasik Kamu Alım Direktifi ve Yeni $A B$ Sektörler Direktifi’nde DAS’ın yürürlükte olacağı süreye ilişkin bir sınırlama getirilmemiştir. Bazı durumlarda örneğin gelişmekte olan bir piyasanın teşvik edilmesinin istenmesi veya hizmet sunumunun devamlılığ sağlanmak isteniyorsa daha uzun bir süre belirlenebilecektir. ${ }^{36}$ Diğer durumlarda örneğin alımı düşünülen malların teknolojisi hızla değişiyorsa daha kısa bir zaman süresi belirlemek daha uygun olacaktır. ${ }^{37}$ Şayet idare, DAS’ın geçerlilik süresinde değişikliğe gitmeye karar verirse bu durumda ihale ilan formunu kullanarak Avrupa Komisyonu'na bildirmekle yükümlüdür. ${ }^{38}$ İdare, ihale ilanının yayınlanmasından en az 30 gün sonra belirleyeceği tarihte DAS’a müteșebbislerin katılım için başvuruda bulunacağı tarihi belirler. ${ }^{39}$

DAS dileyen tüm müteşebbislerin katılımına açıktır. Bununla birlikte DAS’a katılabilmek için gerekli şart, yeterlilik kriterlerini sağlamak ${ }^{40}$ ve aynı zamanda bir ihaleye katılabilmede temel şartlardan olan ihale dışı bırakılma gerekçelerinden birini taşımamaktır. İdare, DAS’a katılıma ehil olacak istekli sayısını sınırlandırabilmek amacıyla yeterlilik kriterlerini daha yüksek belirleyemez. DAS’a kabul edilmede belirlenecek yeterlilik kriterleri, orantılı ve DAS’n gerçekleştirilebilmesi için uygun ölçüde olmalıdır. Katılım için yeterlilik kriterlerinin çok yüksek belirlenmesi, orantılılık ve eşit muamele ilkelerinin ihlali anlamına gelecektir.

İdare, DAS’a katılabilmek için yapılan başvuruları, katılım talebinin sisteme iletilmesinden 10 iş günü içinde sonuçlandırır. Bu süre, gerekçelendirilmek suretiyle, ilave dokümanların incelenmesi ihtiyacı veya yeterlilik kriterlerinin karşılanıp karşılanmadığının doğrulanması için ek süreye ihtiyaç olduğu özel durumlarda, 15 iş gününe uzatılabilir. Belirtilen bu sürelerden bağımsız DAS kategorilere ayrılmış ve bu kategori çerçevesinde ilk münferit alıma isteklilerin teklif vermeleri için davet mektubu gönderilmemişse idareler, isteklilerin katılım başvuru taleplerini inceledikleri süreyi uzatabilirler. Bununla birlikte, idarelerin bu uzatma ihtimallerinin olduğu sürenin ne kadar olacağını da ihale dokümanlarında belirtmeleri gerekmektedir. ${ }^{41}$ İdareler, müteşebbislerin DAS’a katılım başvurularını yeterlilik kriterlerine uyup uymadığg çerçevesinde inceledikten sonra mümkün olan en kısa zamanda müteşebbisleri DAS’a katılımlarının kabul edilip edilmediği hakkında bilgilendirmeleri gerekmektedir. ${ }^{42}$ Kanaatimizce bu "mümkün

34- 2014/24/AB, madde 34 (4)(d). Ayrica bkz. 2014/25/AB, madde 52(4)(d).

35- 2014/24/AB, madde 34(8). Ayrica bkz. 2014/25/AB, madde 52(8).

36- Smith, “ Dynamic Purchasing System: Planning”, s.3.

37- İbid.

38- 2014/24/AB, madde 34(8)(a). Ayrica bkz. 2014/25/AB, madde 52(8)(a).

39- 2014/24/AB, madde 34(2)(a). Ayrica bkz. 2014/25/AB, madde 52(2)(a).

40- 2014/24/AB, madde 34(5). Ayrica bkz. 2014/25/AB, madde 52(5).

41 - İbid.

42- İbid. 
olan en kısa süre” muğlaklık içermektedir. DAS kapsamındaki tüm iletişimin elektronik araçlarla gerçekleştirilmesi gerektiği gözönünde bulundurulduğunda bunun için örneğin 3 iş günü gibi bir süre belirlenmesi hem daha belirli bir zaman olacak hem de müteşebbise en geç davet mektubu gönderilmeden önce eksikliklerini tamamlayarak yeniden katılım başvurusunda bulunabilme imkanı verecektir. DAS’a katılımı reddedilen müteşebbis, yeterlilik kriterlerini yerine getirerek tekrar katılım için başvurabilir. Kanaatimizce sistemi dinamik kılan ve aynı zamanda çerçeve anlaşmalardan da ayıran en önemli unsurlardan biri budur.

İdare, ihale ilanında katılım başvurularının sona ereceği son tarihi de belirtir. ${ }^{43}$

DAS’ın ikinci aşaması, DAS kapsamında gerçekleştirilecek alım veya münferit alım için isteklilere davet mektubu gönderilmesiyle başlar. DAS kategorilere ayrılmışsa davet mektubu sadece ilgili kategoriye katılım başvurusu kabul edilen tüm isteklilere gönderilecektir. ${ }^{44}$

İdare, tekliflerin alınması için davet mektubunun gönderilmesinden itibaren en az 10 gün sonrası için bir süre belirler. ${ }^{45}$ İstekliler, tekliflerini elektronik ortamda sisteme iletir. İhale, ihale ilanında belirtilen en düşük fiyat veya fiyat dışı unsurlar dikkate alınarak en iyi teklif veren istekli üzerine bırakılır. ${ }^{46}$ Sözkonusu isteklinin yeterlilik beyanındaki şartları taşıdığ 1 ve yasaklı olup olmadığ teyit edilerek on günlük bekleme süresinin (standstill period) ardından kendisi ile sözleşme imzalanır.

İdare, DAS’ın gerçekleştirildiği herhangi bir zamanda sisteme kabul edilen isteklilerden güncellenmiş yeterlilik beyanını sunmasını talep edebilir. Bu durumda bu isteklinin idarenin bunu talep ettiği tarihten en geç 5 iş günü içinde sunması gerekmektedir. ${ }^{47} \mathrm{Bu}$ bağlamda DAS’a ilk aşamada başvuru kriterlerini karşılayıp katılımı kabul edilen bir istekli, DAS’ın gerçekleştirilmesi sırasında sonradan ihale dışı bırakılmasını gerektirecek koşulların ortaya çıkması durumunda DAS'tan ihraç edilebilecektir.

DAS çerçevesinde isteklilerin aşırı düşük teklif sunması durumunda, Yeni AB Klasik Kamu Alım Direktifi ve Yeni AB Sektörler Direktifi'nin aşırı düşük tekliflerin değerlendirilmesine ilişkin düzenlemeleri ${ }^{48}$ esas alınacaktır. Bu durumda örneğin aşırı düşük bulunan teklif reddedilebilecekken isteklinin DAS’tan tamamen çıkartılması sözkonusu olamayacaktır.

44- Susie Smith, “Operating a Dynamic Purchasing System”, (23.6.2016), https://www.publiclawtoday.co.uk/ procurement-and-contracts/354-procurement-features/30621-operating-a-dynamic-purchasing-system, (17.11.2018), s.1.

45- 2014/24/AB, madde 34 (2)(b). Ayrica bkz. 2014/25/AB, madde 52(2)(b).

46- 2014/24/AB, madde 34 (6). Ayrica bkz. 2014/25/AB, madde 52(6).

47- 2014/24/AB, madde 34 (7). Ayrica bkz. 2014/25/AB, madde 52(7).

48- 2014/24/AB, madde 69. Ayrica bkz. 2014/25/AB, madde 84. 
Bir istekli, DAS’a katılımı kabul edildikten sonra ancak ihale dıșı bırakma nedenlerinden birinin ortaya çıkması veya yeterlilik kriterlerini karşılayamaz duruma gelmesi durumunda bu sözkonusu olabilecektir. ${ }^{49}$

İdareler, DAS gerçekleştirerek bir alım düzenlediklerinde bu alıma ilişkin bilgileri (idarenin adı, idarenin adresi, alımın konusu, türü, değeri, miktar $1,{ }^{50}$ şayet idare alımı DAS kullanarak vermekten vazgeçmişse gerekçeleri $)^{51}$ içeren bir rapor hazırlamakla yükümlüdür. Dinamik Alım Sistemine ne başvuru ne de katılım aşamasında müteşebbislerden herhangi bir ücret alınmaz. ${ }^{52}$

\section{Şekil 1: Dinamik Alım Sistemi'nin Akış Şeması}

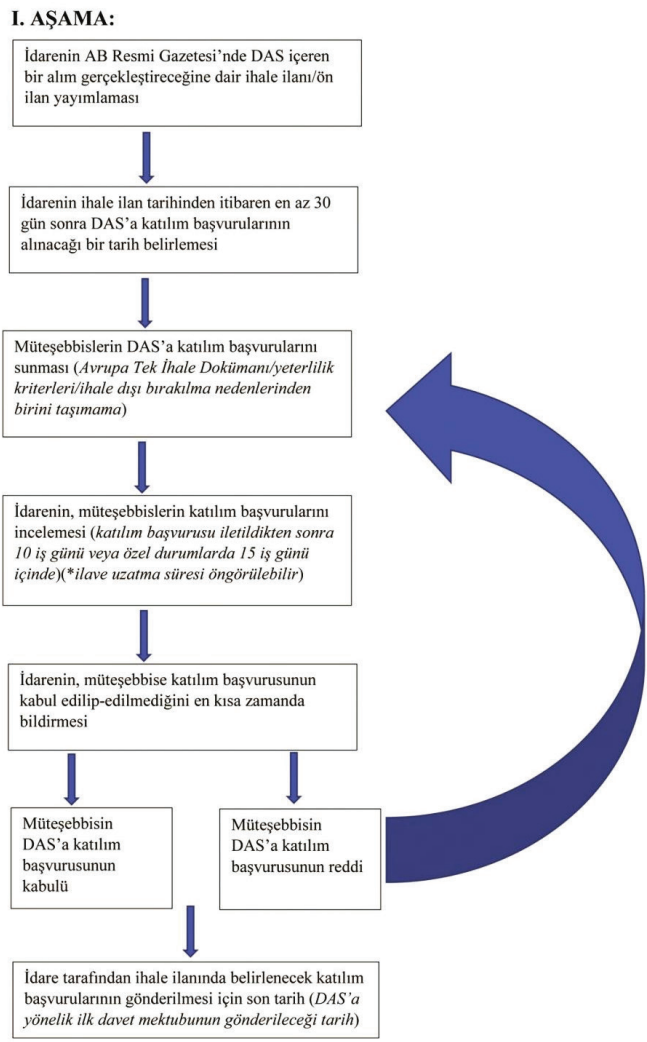

II. AŞAMA:

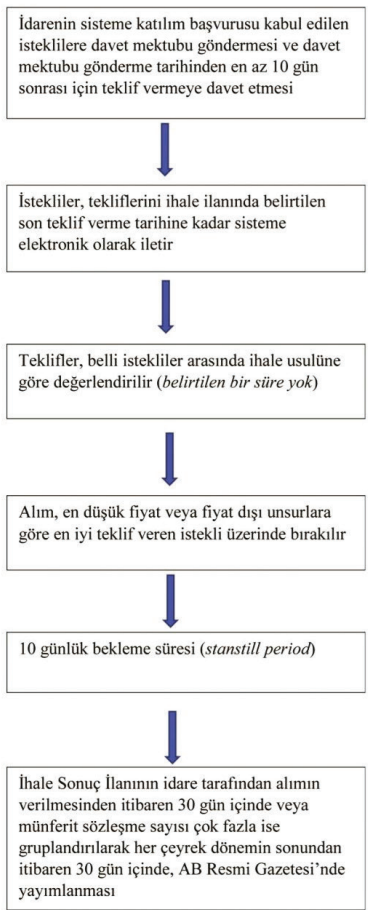

Kaynak:https://www.slideshare.net/SIGMA2013/presentation-sigma-public-

49- Smith, "Operating a Dynamic Purchasing System", s.3.

50- 2014/24/AB, madde 84 (1)(a).

51- 2014/24/AB, madde $84(1)(\mathrm{g})$.

52-2014/24/AB, madde 34 (9). Ayrica bkz. 2014/25/AB, madde 52(9). 
procurement-workshop-dynamic-purchasing-systems-turkey-10-april-2018 ${ }^{53}$

Dinamik Alım Sistemi, merkezi satın alma birimleri tarafından da kullanılabilir. ${ }^{54}$ Diğer taraftan farklı $\mathrm{AB}$ üyesi devletlerden birkaç idare biraraya gelerek bir alımı, DAS kullanarak ortaklaşa gerçekleştirebilir. Bunun için gerekli şart, sözkonusu alımın uluslararası bir anlaşma tarafından düzenlenmemiş olmasıdır. Bu durumda taraflar, her bir tarafın sorumlu olduğu hususlar, usulün nasıl işletileceği, alımı yapılacak mal, hizmet, yapım işinin dağılımı, sözleşmelerin imzalanmasını içeren bir anlaşma hazırlar. ${ }^{55}$

Çerçeve anlaşmalarla karşılaştırıldı̆̆ında en fazla 4 yıl süre için yapilabilen çerçeve anlaşmaların aksine Yeni AB Klasik Kamu Alım Direktifi ve Yeni AB Sektörler Direktifi'nde DAS’ın geçerlilik süresine ilişkin herhangi bir kısıtlama bulunmamaktadır. ${ }^{56}$ Yine çerçeve anlaşmalardan farklı olarak DAS’a kabul edilecek istekli sayısında herhangi bir sınırlama olamaz. Bu bağlamda yeterlilik kriterlerini karşılayan ve ihale dışı bırakılma nedenlerinden birini taşımayan her istekli, sisteme katılım başvurusunda bulunabilir. Sisteme katılımı kabul edilmesi durumunda da teklif vermeye davet edilir. ${ }^{57}$

Ayrıca DAS isteklilerin ilk aşama sona erinceye kadar davet mektubu göndermeden önce katılım başvuruları reddedilmiş dahi olsa veya DAS kategorilere ayrılmışsa davet mektubu gönderilmemiş olan kategoriye de sisteme katılabilmek için aranılan yeterlilik kriterlerini yerine getirerek tekrar başvurabilme imkanı tanıdığından çerçeve anlaşmalarla karşılaştırıldığında rekabete çok daha açık bir araçtır. ${ }^{58}$ Bu mülahazalar nedeniyle Leanne Edwards, daha fazla isteklinin katılımına ve rekabete daha açık olan DAS’ın kullanımının yaygınlaşmasının ileride çerçeve anlaşmaların gerçekleştirilmesinin sona ermesine yol açabilecek bir gelişme teşkil edebileceği değerlendirmesinde bulunmaktadır. ${ }^{59}$

DAS kapsamında e-eksiltmeden de faydalanılabilir. ${ }^{60}$ Ayrıca idareler, DAS kapsamındaki münferit alımlardan birini (veya tamamını) tekliflerin elektronik katalog (e-katalog) ile sunulmasına dayalı olarak değerlendirilmesi şeklinde de ihale edebilir. ${ }^{61}$

53-Paul Smith, "Public Procurement Workshop: Dynamic Purchasing Systems”, (10.4.2018), https://www.slideshare.net/SIGMA2013/presentation-sigma-public-procurement-workshop-dynamic-purchasing-systems-turkey-10-april-2018, (12.12.2018), s.(20-21).

54- 2014/24/AB, madde 37 (1). Ayrica bkz. 2014/25/AB, madde 55(1).

55- 2014/24/AB, madde 39 (4). Ayrica bkz. 2014/25/AB, madde 57(4).

56- Smith, "Public Procurement Workshop: Dynamic Purchasing Systems", s.16.

57- İbid.

58- İbid.

59-Leanne Edwards, “The Evidence Behind Using DPS in Procurement”, (24.3.2016), https://www.procurious. com/procurement-news/evidence-using-dps-procurement, (20.11.2018), s.1.

60 - 2014/24/AB, madde 35 (2). Ayrica bkz. 2014/25/AB, madde 53 (2).

61- 2014/24/AB, madde 36 (6). Ayrica bkz. 2014/25/AB, madde 55(6). 
DAS, birçok basit rejim hizmetlerinde örneğin okul ve sosyal bakım hizmetleri, taşımacılık hizmetlerinde uygulanmaktadır. Basit rejim hizmetlerinde, usullere ilişkin gereklilikler temel düzeyde aranmakta, birçok ayrıntılı prosedürel gereklilikler talep edilmeyerek kolaylık sağlanmaktadır. Bu, bir idarenin basit rejim çerçevesinde DAS’ı uygulamasını kolaylaştırmaktadır. Bununla birlikte DAS kullanarak basit rejim gerçekleştirecek bir idare, bu kolaylıklara rağmen her zaman AB Antlaşması'nın genel hükümleri olan şeffaflık, eşit muamele ve orantılılık ilkelerine uymak zorundadır. ${ }^{62}$

Kamu alımları çerçevesinde uygulanmakta olan şikayet mekanizmasındaki mevcut kurallar, DAS ile bir alımın gerçekleştirilmesine de benzer şekilde uygulanmaktadır. $\mathrm{Bu}$ bağlamda istekliler, bir sürecin askıya alınması veya bir kararın yeniden gözden geçirilmesi gibi ara tedbirlere de başvurabileceklerdir. Aynı zamanda istekliler, bir idarenin davet mektubu göndermeden DAS’ ${ }_{1}$ doğrudan teminle gerçekleştirdiğini tespit etmeleri durumunda düzenleyici kurum veya mahkemeden tüm DAS sürecinin askıya alınmasını da talep edebileceklerdir. ${ }^{63}$

\section{YENİ AB KLASİK KAMU ALIM DİREKTIFİ VE YENİ AB SEKTÖRLER DİREKTİFI İLE GETİRILEN DEĞİȘİLIKKLER:}

Dinamik Alım Sistemi, 2004/18/AT sayılı Eski AB Klasik Kamu Alım Direktifi ve 2004/17/ AT sayılı Eski AB Sektörler Direktifi'nin “Tanımlar ve Genel İlkeler” in yer aldığı I. başlığının 1. maddesinde tanımlanmıştır. ${ }^{64}$ Sözkonusu maddelerde yer alan müteşebbisin sisteme katılabilmek için bir ön teklif (indicative tender) sunması zorunluluğu, ${ }^{65}$ sistemin işleyişine ek yük getirdiği değerlendirilerek kaldırılmıştır. Ardından Dinamik Alım Sistemi’nin işletilmesi için belirlenen açık ihale usulü ${ }^{66}$ yukarıda değindiğimiz üzere belli istekliler arasında ihale usulüne dönüştürülmüştür.

Hem eski hem de yeni AB Klasik Kamu Alım Direktifi ve Sektörler Direktifi'nde, isteklilerin sisteme katılabilmek için idare tarafından 10 iş günü (özel durumlarda 15 iş gününe uzatabilme imkanı) içinde başvurusu incelendikten sonra sisteme kabul edilip edilmediklerine dair bilgilendirmenin "mümkün olan en kısa zamanda" gerçekleștirilmesine dair muğlak ifade yerini korumaktadır. ${ }^{67}$

DAS’ın işleyişini zorlaştıran ve idarelere ek işlem yükü getirdiği uygulamada görülen

62- Smith, “Dynamic Purchasing System: Planning”, s.2.

63- Smith, "Operating a Dynamic Purchasing System", s.4.

64- 2004/18/AT, madde 1. Ayrica bkz. 2004/17/AT, madde 1.

65- İbid., madde 1. Ayrica bkz. 2004/17/AT, madde 1.

66- İbid., madde 33(2). Ayrıca bkz. 2004/17/AT, madde 15(2).

67- İbid., madde 33(4). Ayrıca bkz. 2004/17/AT, madde 15(4). 
davet mektubu yayımlamadan önce basitleştirilmiş ihale ilanı (simplified contract notice) yayımlaması ve şayet DAS kategorilere ayrılmışsa her bir münferit alımla ilgili müteşebbislere davet mektubu göndermeden önce bunu yayınlaması zorunluluğu da kaldırılmıştır. ${ }^{68}$

Eski AB Klasik Kamu Alım Direktifi ve Eski AB Sektörler Direktifi'nde DAS’ın en fazla 4 yıl süre ile gerçekleştirileceğine ${ }^{69}$ dair zaman kısıtı artık yer almamaktadır.

Son olarak idarelerin DAS kullanarak bir alım gerçekleştirmeleri durumunda alımın sonuçlandırılması sonrasında yayımlayacakları sonuç ilanını yayımlama zorunluluk süresi, 48 günden (veya çeyrek dönemler çerçevesinde gruplandırması durumunda, gruplandırılmış ilanları her bir çeyrek dönemin sonundan itibaren 48 gün içinde yayınlanması zorunluluğu $)^{70}$ yukarıda değindiğimiz üzere 30 güne düşürülmüștür. Eski AB Sektörler Direktifi'nde kuruluşlara daha büyük bir zaman dilimi esnekliğiyle 2 ay olarak belirlenen bu süre, ${ }^{71}$ Yeni AB Sektörler Direktifi'nde, Yeni AB Klasik Kamu Alım Direktifi'yle eşitlenerek yukarıda değindiğimiz üzere 30 gün olarak tayin edilmiştir.

\section{DİNAMIKK ALIM SISTEMİ KULLANIMININ AVANTAJ VE DEZAVANTAJLARI}

\subsection{Dinamik Alım Sistemi Kullanımının Avantajları}

Dinamik Alım Sistemi kullanımının başlıca avantajları; piyasaya yeni oyuncuların/ isteklilerin girmesine imkan vermesi, diğer alım usullerine göre daha hızlı gerçekleştirilebilme ve bu sayede idarelerin ihtiyaçlarının hızlı karşılanmasına katkıda bulunması, KOBİ'lerin kamu alımlarına katılım imkanını arttırması, isteklilerin DAS’a davet mektubu gönderilinceye kadar başvuruları reddedilmiş dahi olsa eksikliklerini tamamlayarak yeniden başvurup sisteme katılabilme imkanı tanıması ve bu sayede şekil şartlarındaki eksikliklerden dolayı ihale dışı bırakılmalarının önüne geçilerek mümkün olan en fazla katılımcı ile rekabetin en yüksek oranda tesis edilmesine olanak sağlaması olarak sayılabilir. ${ }^{72}$ Paul Smith bunlara ilaveten, Dinamik Alım Sistemi'nin idareler için istekli veri tabanı oluşmasını sağlamasına ve pazara yeni giren müteşebbislerin ihale imkanlarından faydalanmasının önünü açarak yenilikçiliği teşvik etmesine dikkat çekmektedir. ${ }^{73}$ Ayrıca az miktarda alım ihtiyacı olan idarelerin bu tür alımlar için teklif

68- İbid., madde 33(4). Ayrıca bkz. 2004/17/AT, madde 15(5).

69- İbid., madde 33(7). Ayrıca bkz. 2004/17/AT, madde 15(7).

70- İbid., madde 35(4).

71- 2004/17/AT, madde 43(1).

72- Procurement Journey, "Dynamic Purchasing Systems (DPS)", https://www.procurementjourney.scot/dynamic-purchasing-systems-dps, (20.11.2018), s.3.

73- Smith, "Public Procurement Workshop: Dynamic Purchasing Systems", s.(17-18). 
vermek isteyebilecek KOBİlerle çalışma imkanı bulması ve bunun da KOBİlerin idarelerin özel ihtiyaçlarına özel çözümler getirmesine imkan yaratarak yerel işletmelerin desteklenmesinin önünü açması, DAS çerçevesinde katılımcı sayısının sınırlandırılmaması nedeniyle katılım başvurusu kabul edilen çok sayıda istekli ile daha düşük fiyatlarla alım yapabilme veya fiyat dışı unsurların da kullanımı ile en düşük fiyata en kaliteli ve en düşük maliyetli alımı yapabilme imkanı sağlayarak devletin yaptığg harcamalarda parasının en iyi karşılığını alabilmesine (value for money) hizmet etmesi, çok sayıda işlemi biraraya getirip yönetimi daha kolay tek bir sürece dönüștürmek suretiyle alımların topluca yapılmasına izin vermesi ve bu şekilde alıma teklif vermek isteyen müteşebbislerin tek bir platformda toplanmasını sağlaması, alternatif mal, hizmet alımı ve yapım işi imkanı ile geniş bir yelpazede müteşebbise firsat tanıyarak benzer veya birbirini ikame edebilecek ürünlerle kapasite sorunlarının giderilmesine katkıda bulunmasını da eklemektedir. ${ }^{74}$ Diğer taraftan DAS, idareler açısından tekliflerin, usulün ilerleyen aşamalarında geliştirilmesine imkan vermek suretiyle ${ }^{75}$ en iyi alımın yapılabilmesine de katkıda bulunmaktadır.

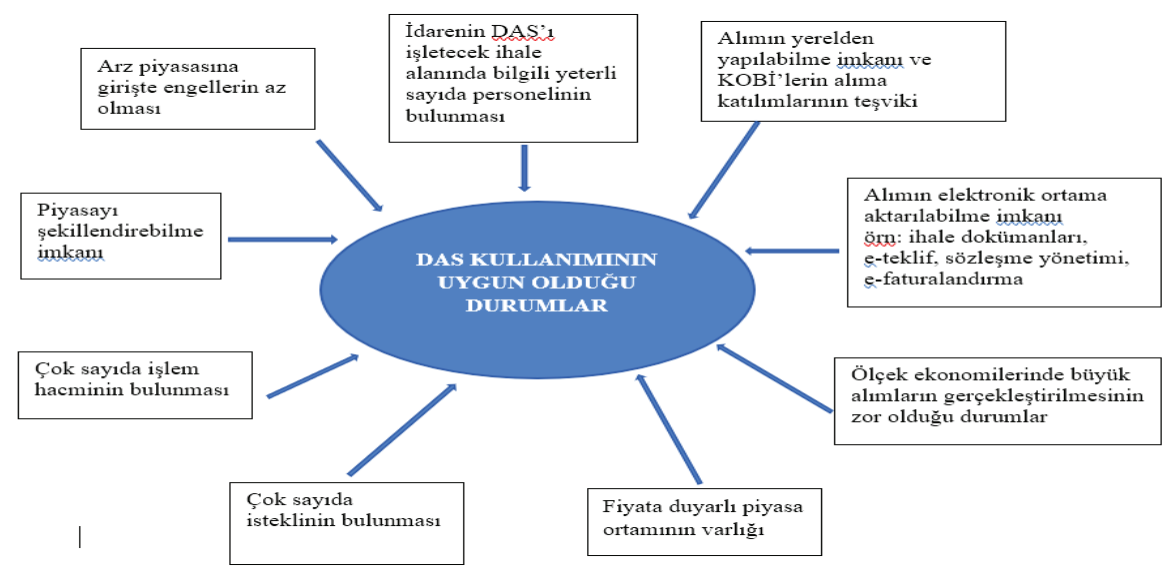

Kaynak: https://www.procurementjourney.scot/dynamic-purchasing-systems-dps ${ }^{76}$

\subsection{Dinamik Alım Sistemi Kullanımının Dezavantajları}

Paul Smith’in de vurguladığı üzere tek seferlik alımlar ve karmaşık yapıdaki alımlar, DAS için uygun değildir. ${ }^{77}$ Çerçeve anlaşmalar ile karşılaştırıldığında DAS daha esnek bir alım aracı olarak ortaya çıkmaktadır ancak yönetilmesi için sürekli mesai gerektirmektedir. ${ }^{78}$ Kanaatimizce fikri mülkiyet (örneğin tasarım yarışmaları) kapsamındaki alımların da

74-İbid., s.(24-26).

75-Acquistinretepa, "Dynamic Purchasing System”, https://www.acquistinretepa.it/opencms/opencms/menu_livello_I/header/Inglese/TOOLS/Dynamic_Purchasing_System.html, (21.11.2018), s.1.

76- Procurement Journey, "Dynamic Purchasing Systems (DPS)”, s.2.

77- Smith, "Public Procurement Workshop: Dynamic Purchasing Systems”, s. 27.

78- İbid.,s.39. 
DAS ile gerçekleştirilmesi uygun olmayacaktır.

DAS kullanımında idareler açısından üzerinde önemle durulması gereken husus, DAS’ın doğrudan temin aracı olarak kullanılamayacağıdır. DAS’a sadece bir isteklinin başvurduğu istisnai durumlar hariç tek alıcıyla alım düzenlenerek DAS’ın bir nev'i doğrudan temin aracı olarak kullanılmasına izin verilemez. ${ }^{79} \mathrm{Bu}$ bağlamda belirtmek gerekir ki, Avrupa Komisyonu doğrudan temini, alım usulleri içinde en kötü uygulama olarak değerlendirmekte ve AB Antlaşması'nın genel ilkelerinin ihlali olarak nitelendirmektedir. Sözkonusu nedenle DAS’ın doğrudan teminin bir aracına dönüştürülmesi durumunda Avrupa Komisyonu yasal işlem başlatabilecektir. ${ }^{80}$

\section{AVRUPA BİRLİĞİ ÜYE DEVLETLERINDE DİNAMİK ALIM SİSTEMİNİN KULLANILMASINA İLIŞKIN ÖRNEK UYGULAMALAR}

İlk kez 2004 yılındaki Eski AB Klasik Kamu Alım Direktifi ve Eski AB Sektörler Direktifi ile mevzuatta düzenlenen DAS, ilk etapta idareler tarafından kullanımı elverişli olmadığı değerlendirmesiyle kendisine uygulamada çok yer bulamamıştır. Uygulamadan gelen bu geri bildirimle $A B$ yukarıda değindiğimiz üzere Yeni $A B$ Klasik Kamu Alım Direktifi ve Yeni AB Sektörler Direktifi’nde DAS’ın işleyişinde değişikliğe giderek kolaylaştırması sonrasında DAS’ın uygulanması yaygınlaşmıştır. Bu bağlamda DAS, AB üye devletlerinde başta Birleşik Krallık ve ona bağlı İskoçya ile İtalya’da idareler tarafından kamu alımlarında yaygın bir şekilde kullanılmaktadır. Sözkonusu örnek uygulamalara aşağıda yer verilmiştir.

\subsection{Birleşik Krallık’ın Dinamik Alım Sistemi’ni Uygulaması:}

DAS, Birleşik Krallık’ta yukarıda değindiğimiz DAS’’n idarelere getirdiği işlem yükü nedeniyle 2014 yılında AB’nin Yeni AB Klasik Kamu Alım Direktifi ve Yeni AB Sektörler Direktifi'nde değişikliğe gidinceye kadar yaygın bir kullanım olanağı bulamamıştır. Sözkonusu değişikler üzerine Birleşik Krallık, 26 Şubat 2015 tarihinde yürürlüğe giren Kamu İhale Tüzügü̈nü düzenlemiş ${ }^{81}$ ve bahsekonu tüzüğün "Elektronik ve Toplu Alımlara İlişkin Teknik ve Araçlar” başlıklı dördüncü bölümünün 34. maddesinde DAS’a ayrı bir başlık altında yer vermiştir. ${ }^{82}$ Sözkonusu madde hükmünün lafzı incelendiğinde Birleşik Krallık’n ulusal düzenlemesinin Yeni AB Klasik Kamu Alım Direktifi ve Yeni AB Sektörler Direktifi ile birebir örtüştüğü anlaşılmaktadır.

\footnotetext{
79-Crown Commercial Service, "The Public Contracts Regulations 2015: Dynamic Purchasing System", http:// www.lpp.nhs.uk/media/91686/Guidance_on_Dynamic_Purchasing_System.pdf, (20.11.2018),s.10. 80- İbid.

81-GOV.UK, "Public Procurement Policy", https://www.gov.uk/guidance/public-sector-procurement-policy\#procurement-policy-notes, (16.11.2018), s.1.

82-GOV.UK, “The Public Contract Regulations 2015”, (4.2.2015), http://www.legislation.gov.uk/uksi/2015/102/ pdfs/uksi_20150102_en.pdf, (20.11.2018), madde 34 .
} 
Birleşik Krallık'ta Kraliyet Ticari Hizmet (Crown Commercial Service) portalı kamu alımlarının elektronik ortamda gerçekleştirilmesine imkan veren en büyük elektronik platformdur. ${ }^{83}$ Sözkonusu platform kapsamında idareler, DAS ile alım da gerçekleştirebilmektedir.

Birleşik Krallık’ta DAS ile alımlar gerçekleştirilmesine hizmet eden bir başka kuruluş, tamamı kamuya ait olan ve belediyelerden okullara, kamu kuruluşlarına, yardım derneklerine uzanan geniş bir kitleye mal ve hizmet tedarik eden, 13 yerel idarenin sahip olduğu YPO'dur. ${ }^{84} 1974$ yılında kurulan YPO, merkezi satın alma birimi olarak faaliyet göstermektedir. ${ }^{85}$

Birleşik Krallık’a bağlı İskoçya'da ulusal düzeyde elektronik olarak gerçekleştirilecek kamu alımları için 2008 yılında İskoç Kamu İhaleleri (Public Contracts) portalı oluşturulmuştur. ${ }^{86}$ Sözkonusu platform üzerinden hem $\mathrm{AB}$ eşik değer üstü alımlar hem de eşik değer altı alımlar gerçekleştirilebilmekte olup 2018 yılında 33 eşik değer altı, 14 eşik değer üstünde alım için ilana çıkılmıştır. ${ }^{87}$ İskoç Alım İdaresi, Dinamik Alım Sistemi kapsamında tekliflerin değerlendirilmesinde idarenin teknik/kalite değeri için \%40-\%80, fiyat için ise \%20-\%60 aralığında bir oranı seçerek alımı fiyat dışı unsurları dikkate alarak gerçekleştirebilmesini düzenlemektedir. İdare sözkonusu değerlere ilişkin seçeceği oranı, ihale ilanı ve ihale dokümanında belirtecektir. ${ }^{88}$

İskoçya’da DAS genel olarak 1 yıllık süreç için uygulanmakta ve gerekli görüldüğünde bir yıl daha uzatabilmektedir. Bununla birlikte DAS için bir süre kısıtlaması bulunmamaktadır. Diğer taraftan İskoç Alım İdaresi (Scottish Procurement), DAS’ın işleyişini dilediği anda durdurabilme hakkını saklı tutmaktadır. ${ }^{89}$

\section{2 İtalya'nın Dinamik Alım Sistemi'ni Uygulaması:}

İtalya’nın Ekonomi ve Maliye Bakanlığı, 1997 yılında, idarelere e-alım yöntemleri konusunda hizmet vererek kamu alım piyasasına müteşebbislerin daha fazla katılımı ve rekabetin artmasıyla kamu kaynaklarının daha etkin, verimli, şeffaf kullanılmasını

83- Crown Commercial Service "About Us", https://www.crowncommercial.gov.uk/s/about-ccs, (18.11.2018),s.1. 84- YPO, “About YPO”, https://www.ypo.co.uk/about, (19.11.2018), s.1.

85- YPO, “History of YPO”, https://www.ypo.co.uk/about/history, (19.11.2018), s.1.

86- Public Contracts Scotland, "About Us", https://www.publiccontractsscotland.gov.uk/aboutus/aboutus_main. aspx, (18.11.2018), s.1.

87- Public Contracts Scotland, "Search for Notices", https://www.publiccontractsscotland.gov.uk/search/search_mainpage.aspx, (4.12.2018), s.1.

88- Procurement Journey, "Scottish Procurement Suppliers Guide:Digital Services-Dynamic Purchasing System", https://www.procurementjourney.scot/sites/default/files/documents_library/Digital\%20Services\%20-\%20 DPS\%20-\%20Supplier\%27s\%20Guide.pdf, (20.11.2018), s.8.

89- İbid., s.3. 
sağlamak amacıyla bir kamu şirketi olan Consip’i kurmuştur. ${ }^{90}$ Consip, idarelerin ihtiyaçları doğrultusunda alım usulleri geliştirmekte ve idarelere e-alım araçları konusunda danışmanlık hizmeti vermektedir.91 İtalyan Ekonomi ve Maliye Bakanlığı, 2000 yılında İdarelerin Satın Alımlarını Rasyonelleştirme Programı'nı (The Programme for the Rationalization of the Purchases of Public Authorities) oluşturmuş ve sözkonusu programı yürütmek üzere Consip'i görevlendirmiştir. Bu program çerçevesinde Consip'in bünyesinde hem $\mathrm{AB}$ eşik değer altına hem de üstüne tekabül eden miktardaki alımların elektronik olarak gerçekleştirilebilmesi amacıyla bir e-ihale platformu olan Acquistinretepa kurulmuştur. Acquistinretepa çerçevesinde ilk kez 2002 yılında AB eşik değerin altındaki alımların elektronik olarak gerçekleştirildiği Kamu İdareleri İçin Elektronik Piyasa Ortamı (Electronic Marketplace for Public Administrations- MePA) oluşturulmuş, 2011 y1lında Consip merkezi satınalma kuruluşu görevini üstlenmiş, 2012 yılında da konumuz olan Dinamik Alım Sistemi platforma dahil edilmiştir ${ }^{92}$ Acquistinretepa'nın içinde halihazırda elektronik olarak yürütülmekte olan 4 hizmet sağlanmaktadır. Bunlar; çerçeve anlaşmalar, çerçeve sözleşmeler, elektronik piyasa ortamı (electronic market place-MePA) ve Dinamik Alım Sistemi'dir. ${ }^{93}$ İtalya'da DAS hem AB eşik değer altı hem de eşik değer üstü alımlar için uygulanmaktadır. ${ }^{94}$

İtalya'da DAS kapsamında özellikle şu alımlar gerçekleştirilmiştir: ${ }^{95}$

- Tıbbi malzeme alımı (ilaç, kan ürünleri, aşı vs.),

- Bilişim Teknolojileri (donanım, yazılım ve bilişim teknolojileri hizmetleri),

- Antiseptik ve dezenfektan ürünleri,

- Yemek hizmetleri için gıda ve çözülebilir malzemelerin alımı,

- Engelli kişilere yardımcı olacak ürünler.

2017 yılında İtalya’da DAS kullanılarak eşik değer altı ve eşik değer üstü toplam 4.060 adet

90- Gian Lugi Albano; "The Role of Consip S.p.A in the Italian Centralized Public e-Procurement System", (11.11.2015), https://www.kozbeszerzes.hu/data/filer_public/7d/36/7d365d0c-8ded-486c-8636-9addff996334/ en_gian_luigi_albano_centralization_italy_consip_11nov2015.pdf, (17.11.2018), s.6.

91- Acquistinretepa, "Program: Stakeholders”, https://www.acquistinretepa.it/opencms/opencms/program_eng. html, (17.11.2018), s.1.

92- Acquistinretepa, "How it Works:Our History”, https://www.acquistinretepa.it/opencms/opencms/program how_itWorks.html, (17.11.2018), s.1.

93-Acquistinretepa,"Purchasing Tools Avaliable”, https://www.acquistinretepa.it/opencms/opencms/program eng.html , (17.11.2018), s.1.

94- Acquistinretepa, “Dyanmic Purchasing System”, s.1.

95- Luca Mastrogregori, “The Dynamic Purchasing Systems: Consip’s Implementation”, (22.9.2014), https:// www.oecd.org/governance/procurement/toolbox/search/Italy-Dynamic-Purchasing-Systems.pdf, (20.11.2018), s.2. 
alım gerçekleştirilmiştir. Sözkonusu alımların değeri ise 4.04 milyar €’dur.. ${ }^{96}$

CONSIP, DAS ile alım yapılmak suretiyle geleneksel alım yöntemlerine kıyasla maddi olarak \%18, ${ }^{97}$ zaman yönünden ise $\% 20$ tasarruf yapıldığını değerlendirmektedir. ${ }^{98}$

\section{TÜRK KAMU ALIM MEVZUATI'NDA E-İHALE VE DİNAMİK ALIM SİSTEMİ}

Kamu İhale Kurumu elektronik ihalenin uygulanabilmesine yönelik çalışmalarına daha kuruluşunun ilk yıllarında başlamıştır. Bu çalışmalara AB Kamu Alımları Mevzuatı́na 2004 yılında dahil edilen ve Türk Kamu Alım Mevzuatı'na AB müktesebatı ile uyum çerçevesinde 2008 yılında aktarılan ve tamamen elektronik ortamda gerçekleştirilmek üzere tasarlanmış bir araç olan DAS da dahildir. Bu çerçevede öncelikle Kamu İhale Kurumu'nun elektronik ihale konusunda gerçekleştirdiği çalışmalar ve bu alanda gelinen düzeye değinecek olursak; Kamu İhale Kurumu farklı alım usullerine uygulanacak e-ihaleyi hayata geçirebilmek amacıyla öncelikle Eylül 2003'te, gerçekleştirilecek her ihaleye ilişkin bir bilgi sistemi oluşturabilmek amacıyla İhale Bilgi Sistemi’ni tasarlamıştır. İhale Bilgi Sistemi kapsaminda her ihalenin elektronik ortamda bir kayıt numarası alması, ihalelere katılmaktan yasaklanan gerçek ve tüzel kişilerin ihaleye katılımlarını engellemek için yasaklılık teyit işlemleri (e-teyit) ve doğrudan temin uygulamaları devreye alınmıştır. ${ }^{99}$ Ardından ihalelere ilişkin ilanların istekliler tarafından minimum hata ile elektronik ortamda hazırlaması ve gönderilmesine yardımcı olacak bir program olan İhale İlan Modül'ü oluşturulmuştur. Elektronik ilan (e-ilan), isteklilerin İhale İlan Modül'ü aracılığıyla ilanları Kamu İhale Kurumu'na göndermeleri ve burada ilgili personel tarafından ön kontrolden geçirildikten sonra Kamu İhale Kurumu'nun web sayfasında yer alan Elektronik Kamu İhale Bülteni’nde yayınlanmasıyla 2005 yılında hayata geçirilmiştir. ${ }^{100}$ Kasım 2005 'te İhale Bilgi Sistemi’nin kapsamı genişletilerek idare, istekli ve vatandaş girişi olmak üzere üç bölümden oluşan Kamu Satınalma Platformu oluşturulmuştur. ${ }^{101} 2007$ yılından itibaren ise kamu alımlarına ilişkin ilanların kağıt ortamında yayınlanmasına son verilerek sadece elektronik ortamda Elektronik Kamu İhale Bülteni'nde yayınlanması kararlaştırılmıştır. ${ }^{102} 2008$ yılında gerçekleştirilen kanun

96- Acquistinretepa, "Figures”,https://www.acquistinretepa.it/opencms/opencms/english/English_figures.html, (20.11.2018),s.1.

97- Mastrogregori, “The Dynamic Purchasing Systems: Consip’s Implementation”, s.8.

98- İbid., s.7.

99- T.C. Kamu İhale Kurumu, "2003 Yllı Faaliyet Raporu”, (23.7.2004), http://www2.ihale.gov.tr/Duyurular2012/2003_yili_faaliyet_raporu.pdf, (1.9.2019), s. 4.

100- T.C. Kamu İhale Kurumu, “2004 Y1lı Faaliyet Raporu”, 2005, http://www2.ihale.gov.tr/Duyurular2012/2004_ yili_faaliyet_raporu.pdf, (1.9.2019), s.76.

101- T.C. Kamu İhale Kurumu, “2005 Yilı Faaliyet Raporu”, 2006, http://www2.ihale.gov.tr/arge/2005_yili_Faaliyet_Raporu.pdf, (1.9.2019), s.89.

102- T.C. Kamu İhale Kurumu, “2006 Y1lı Faaliyet Raporu”, 2007, https://www.ihale.gov.tr/kurum_faaliyet_ra- 
değişikliği ve 4734 sayılı Kamu İhale Kanunu’na eklenen EK Madde 1 ile düzenlenen hedefleri gerçekleştirebilmek ve e-ihaleyi tam anlamıyla hayata geçirebilmek amacıyla Kamu Satın alma Platformu üç bileşenden altı bileşene çıkartılarak (idare bileşeni, istekli bileşeni, vatandaş bileşeni, kurum bileşeni, çağrı merkezi ve entegrasyonlar) Elektronik Kamu Alımları Platformu (EKAP) tesis edilmiştir. ${ }^{103}$

Elektronik ihaleyi uygulamaya geçirmek için ikincil mevzuat hazırlıkları kapsamında Elektronik İhale Uygulama Yönetmeliği ilk kez 25 Şubat 2011 tarihinde yürürlüğe girmiş olup $^{104}$ sözkonusu yönetmelikte en son 13 Haziran 2019 tarihinde değişikliğe gidilmiştir. ${ }^{105}$

Elektronik ihale alanında ilk pilot uygulama, tüm süreçleriyle birlikte Hacettepe Üniversitesi tarafından 4.3.2011 tarihinde 3 kalem eldiven alımı ile mal alımları alanında gerçekleştirilmiştir. ${ }^{106}$ Çerçeve Anlaşmalara ilişkin ilk e-ihale ise 19.6.2013 tarihinde yine pilot uygulama olarak İstanbul Anadolu Güney Kamu Hastaneleri Birliği ve Erzurum Kamu Hastaneleri Birliği tarafından münferit sözleşme süreci tamamen elektronik ortamda yapılmak suretiyle tıbbı cihaz, ilaç alımı ve bilgisayar alımı alanında yine mal alımları kapsamında denenmiştir. ${ }^{107}$

2015 yılında tüm yerli isteklilere EKAP’a kayıt yaptırma zorunluluğu getirilmiş ${ }^{108}$ tebligatların gerçekleştirilmesi de EKAP üzerinden yürütülmeye başlanmıştır. ${ }^{109}$

1 Temmuz 2016'da yaklaşık maliyeti 250 bin TL'ye kadar olan mal ve hizmet alımlarında e-ihale uygulanmaya başlanılmıştır. ${ }^{110}$ Sözkonusu tarihte aynı zamanda AB uygulamalarındaki Avrupa Tek İhale Dokümanı (European Single Procurement Document) örneğinden yola çıkılarak isteklilerin kamu alımlarına katılımlarını kolaylaştıracak "beyan usulü” kullanımına ilk etapta yaklaşık maliyeti 4734 sayılı Kamu İhale Kanununun 13 (b) (2) maddesinde düzenlenen mal ve hizmet alımları için öngörülen üst limitin altında

porlari-25-1.html, (1.9.2019), s.35.

103- T.C. Kamu İhale Kurumu, “2010 Yilı Faaliyet Raporu”, 2011, http://www2.ihale.gov.tr/kik/Belgeler/2010\%20 Y\%C4\%B11\%C4\%B1\%20Faaliyet\%20Raporu.pdf, (2.9.2019), s.42.

104- 25 Şubat 2011 tarih ve 27857 sayılı Elektronik İhale Uygulama Yönetmeliği için bkz. T.C. Resmi Gazete, "Elektronik İhale Uygulama Yönetmeliği”, (25.2.2011), http://www.resmigazete.gov.tr/eskiler/2011/02/20110225-17. htm, (1.9.2019).

105- 13.6.2019 tarih ve 30800 sayılı Elektronik İhale Yönetmeliği’nde Değişiklik Yapılmasına Dair Yönetmelik için bkz. T.C. Cumhurbaşkanlığı Resmi Gazete, "Elektronik İhale Yönetmeliği’nde Değişiklik Yapılmasına Dair Yönetmelik”, (13.6.2019), http://www.resmigazete.gov.tr/eskiler/2019/06/20190613-5.htm, (1.9.2019).

106- Doğukan Demirci, İhale Sürecinin Elektronik Ortama Aktarılması ve Ülke Uygulamaları, Yayınlanmamıș Uzmanlık Tezi, Ankara, Kamu İhale Kurumu, 2014, s.110.

107- Erkan Özdemir, “Çerçeve Anlaşma İhaleleri”, Kamu İhale Dünyası, Cilt 3, No 11, 2018, s. (33-45), s.44.

108- Demirci, İhale Sürecinin Elektronik Ortama Aktarılması ve Ülke Uygulamaları, s. 113.

109- İbid., s.114.

110- Hürriyet, "E-ihaleyle 50 milyon liralık tasarrufun yolu açılacak", (8.8.2018), http://www.hurriyet.com.tr/ ekonomi/e-ihaleyle-50-milyon-liralik-tasarrufun-yolu-acilacak-40921914, (1.9.2019), s.1. 
kalan ve açık ihale usulü ile gerçekleştirilen mal ve hizmet alımlarında başlanılmıştır. ${ }^{111}$ 19 Haziran 2018 tarihinde ise geleneksel yöntemlerle fiziki ortamda gerçekleștirilecek ihalelerde isteklilerin ihalelere katılımlarını kolaylaştırabilmek amacıyla dokuz belgeden oluşan Sunulmayacak Belgeler Tablosu, elektronik ortamda gerçekleştirilecek ihaleler için ise ilgililerin beyan edeceği Yeterlilik Bilgileri Tablosu oluşturularak ihale sürecinde isteklilerin belge hazırlama zaman ve maliyet yükünden büyük ölçüde kurtulmaları sağlanmıştır. Bu sayede isteklilerin 50 milyon TL tasarruf edeceği hesaplanmıștır. ${ }^{112}$

1 Kasım 2018 tarihi itibariyle Avrupa Birliği kamu alımları mevzuatı çerçevesindeki uygulamalara paralel bir şekilde açık ihale usulü ve belli istekliler arasında ihale usulü ile yapılan ihalelerde geçerli teklif sahibi isteklilerin ilk fiyat tekliflerinden daha düşük fiyatlar ile yeniden yarışabilmelerine imkan sağlayan elektronik eksiltme (e-eksiltme) uygulanmaya başlanılmıştır. ${ }^{113}$

2 Ocak 2019 tarihinde ise e-ihale, açık ihale usulü ile yapılan mal, hizmet alımı ve yapım işi ihaleleri, 21. maddenin (f) bendine göre gerçekleştirilen mal ve hizmet alımı ihaleleri ve yeterlilik sertifikası üzerinden yeterlik tespiti yapılan yapım işi ihalelerinin e-ihale ile gerçekleştirilmesinde parasal sınır kaldırılmıştır. ${ }^{114}$

Diğer taraftan 21 Aralık 2018 tarihinden itibaren yabancı isteklilere de EKAP'a kayıt yaptırarak EKAP’tan faydalanabilme imkanı getirilmiştir. ${ }^{115}$

1 Haziran 2019 tarihi itibariyle ise ihale dokümanlarının tamamen EKAP üzerinden ücretsiz olarak e-imza kullanılarak indirilmesi zorunluluğu getirilerek ihale dokümanlarının idarelerden satın alınması uygulamasına son verilmiştir. ${ }^{116}$

Kamu İhale Kurumu tarafından gerçekleştirilen bu çalışmalar sonucunda elektronik ihalenin ilanların elektronik ortamda yayınlanmasından ihale dokümanlarına elektronik olarak erişilebilmesine, elektronik ortamda teklif vermeden farklı ihale usullerinde alımın elektronik ortamda gerçekleştirilmesine kadar birçok aşaması başarıyla tamamlanmıştır. Bu sayede Kamu İhale Kanunu kapsamında gerçekleştirilen yıllık yaklaşık 90 bin ihalenin

111- Doğukan Demirci, "Elektronik İhalede Yeni Bir Adım Beyan Usulü”, Kamu İhale Dünyası, Cilt 1, No 3, 2018, s. (26-33), s.30.

112- Hürriyet, "E-ihaleyle 50 milyon liralık tasarrufun yolu açılacak”, s.1.

113- Milliyet, "İhalelerde Elektronik Eksiltme Yapılabilecek" (19.6.2018), http://www.milliyet.com.tr/ekonomi/ ihalelerde-elektronik-eksiltme-yapilabilecek-2691294, (2.9.2019), s.1.

114- TRT HABER, "Kamu e-ihalelerinde parasal limit kalkıyor”, (6.2.2018), https://www.trthaber.com/haber/ turkiye/kamu-e-ihalelerinde-parasal-limit-kalkiyor-396615.html, (2.9.2019), s.2.

115- Elektronik Kamu Alımları Platformu (EKAP), "Registration of Foreign Natural and Legal Persons on Electronic Public Procurement Platform (EKAP)”, (18.2.2019), https://ekap.kik.gov.tr/ekap/DuyuruDetay.aspx?duyuruID=0da58cf2e0263b07a80b1c96763345957d5cf2f242b418335c4fd9e541220b01, (1.9.2019), s.1.

116- T.C. Kamu İhale Kurumu, "1 Haziran 2019 İtibariyle İhale Dokümanlarının İdarelerden Satın Alınması Uygulaması Kaldırılıyor”, (29.4.2019), https://www.ihale.gov.tr/Duyuru/306/1_haziran_2019_itibariyle_ihale_dokumanlarinin_idarelerden_satin_alinmasi_uygulamasi_kaldiriliyor.html, (1.9.2019), s.1. 
\%90'nı elektronik ortamda yapılabilir hale gelmiştir. ${ }^{117}$ Henüz hayata geçirilmemiş alım araçlarından Dinamik Alım Sistemi’nin hayata geçirilmesine yönelik hukuki düzenlemelere ise yukarıda değindiğimiz üzere 2008 yılında başlanılmıştır. Bu amaçla 4734 sayılı Kamu İhale Kanunu’nda ${ }^{118} 5812$ sayılı Kamu İhale Kanunu ve Kamu İhale Sözleşmeleri Hakkında Kanunda Değişiklik Yapılmasına Dair Kanun'la1 ${ }^{119}$ Dinamik Alım Sistemi düzenlenmiştir. DAS, 4374 sayılı Kamu İhale Kanunu’nun “Tanımlar” başlıklı 4. maddesi ve EK 4. maddesinde yer almaktadır. Gerek 4. maddede yer alan ön teklif (indicative tender) ${ }^{120}$ gerekse buna ilaveten EK 4. maddede yer alan basitleştirilmiş ilan (simplified contract notice) terimleri, DAS’’n işleyişi için açık ihale usulünün seçilmiş olması, ön tekliflerin değerlendirilmesi için onbeş günlük sürenin belirlenmiş olması ve yürürlük süresi olarak da en fazla kırksekiz ayın tayin edilmesi ${ }^{121}$ ibarelerinden Türk Kamu Alım Mevzuatı’nın DAS’a ilişkin düzenlemesinde 2004 yılında yürürlüğe giren Eski AB Klasik Kamu Alım Direktifi ve Eski AB Sektörler Direktifi'ni esas aldığı anlaşılmaktadır. Bununla birlikte, DAS kapsamında mal, hizmet alımları ve yapım işi ihaleleriyle tüm alım türlerinde alım yapılmasına yer veren sözkonusu direktiflerin düzenlemelerinden sadece mal alımları ile alım yapılmasını sınırlandırmasıyla ayrılmaktadır. Bunun temel sebebi DAS’ın Türk Kamu Alım Mevzuatı'na aktarıldığı 2008 yılında da halen AB'de yeni uygulanmakta olan bir alım olması nedeniyle usulün uygulamasına ilişkin yeterli bilgi sahibi olunmaması kaynaklıdır. Diğer taraftan Türk Kamu Alım Mevzuatı hem eski hem de yeni AB Klasik Kamu Alım Direktifi ve Sektörler Direktifi'nde yukarıda değindiğimiz idarenin, sisteme katılmak isteyen isteklilerin ön tekliflerin değerlendirilmesi sonucu hakkında mümkün olan en kısa zamanda ibaresi yerine en geç üç gün içinde katılımlarının kabul veya reddedildiği konusunda bildirimde bulunulacağ ${ }^{122}$ düzenlemesiyle hem muğlaklığ ortadan kaldırmış hem de bu hususu idarenin takdirine bırakmayarak kesin bir süre tayin etmek suretiyle olası bir suiistimalin önüne geçmiştir. EK 5. madde de ise yine AB kamu alım direktiflerindeki düzenlemelere benzer şekilde DAS kapsamında yapılan ihalelerde elektronik eksiltmeden faydalanılabileceği düzenlenmiştir. ${ }^{123}$

117- TRT HABER, "Kamu e-ihalelerinde parasal limit kalkıyor”, s.1.

118- 22/1/2002 tarih ve 24648 sayılı 4734 sayılı Kamu İhale Kanunu için bkz. T.C. Resmi Gazete, "Kamu İhale Kanunu”, http://www.resmigazete.gov.tr/main.aspx?home=http://www.resmigazete.gov.tr/eskiler/2002/01/20020122 htm\&main=http://www.resmigazete.gov.tr/eskiler/2002/01/20020122.htm, (21.11.2018), s.1.

119- 5/12/2008 tarih ve 27075 sayılı 5812 sayılı Kamu İhale Kanunu ve Kamu İhale Sözleşmeleri Kanunu’nda Değişiklik Yapılmasına Dair Kanun için bkz., T.C. Resmi Gazete, "Kamu İhale Kanunu ve Kamu İhale Sözleşmeleri Kanunu’nda Değişiklik Yapılmasına Dair Kanun”, http://www.resmigazete.gov.tr/main.aspx?home=http://www.resmigazete.gov.tr/eskiler/2008/12/20081205.htm\&main=http://www.resmigazete.gov.tr/eskiler/2008/12/20081205.htm, (21.11.2018), s.1.

120- 4734 sayılı Kamu İhale Kanunu, madde 4.

121- İbid., EK Madde 4.

122- İbid.

123- İbid., EK Madde 5. 


\section{SONUÇ:}

Avrupa Birliği, kamu alımlarında elektronik araçlardan faydalanmaya ilk kez 2004 yılında yürürlüğe giren Eski $\mathrm{AB}$ Klasik Kamu Alım Direktifi ve Eski AB Sektörler Direktifi ile başlamıştır. $A B$ bu girişimini 2014 yılında düzenlediği ve 2016 yılında tüm $A B$ üye devletlerinde yürürlüğe giren Yeni AB Klasik Kamu Alım Direktifi ve Yeni AB Sektörler Direktifi ile devam ettirerek bir adım öteye taşımıştır. AB’nin e-ihale ile amaçladığı sadece alımların kağıt ortamından elektronik süreçlere aktarılması değil başta $\mathrm{AB}$ Antlaşması'nın genel ilkeleri olan rekabet, ayrımcılık yapmama, şeffaflık, orantılılık gibi temel ilkelerin bu süreçler sayesinde mümkün olabildiğince çok hayata geçirilerek kamu alımlarına müteşebbislerin daha fazla katılabilmesi, bürokrasinin en aza indirgenmesi, usulsüzlük ve yolsuzlukların önüne geçilerek devletin kamu alımları için yaptığı harcamaları en kaliteli, en düşük fiyat ve maliyetle alabilmesini sağlamaktır.

İlk kez 2004 yılında düzenlenen Eski AB Klasik Kamu Alım Direktifi ve Eski AB Sektörler Direktifi ile mevzuatta kendisine yer bulan ve 2014 yılında düzenlenen Yeni AB Klasik Kamu Alım Direktifi ve Yeni AB Sektörler Direktifi ile işleyişi sadeleştirilip kolaylaştırılan DAS, dileyen ve yeterlilik kriterlerini taşıyan tüm müteşebbislerin katılımına imkan vermesi, tamamen elektronik ortamda gerçekleştirilmesi, KOBİ’lerin kamu alımlarına daha yüksek oranda katılımını sağlayarak yerelliği teşvik etmesi gibi sağladığı birçok fayda ile kamu alımlarında yenilikçiliği teşvik eden bir araçtır. Bu özellikleriyle şayet nasıl uygulanılacağı müteşebbislere iyi öğretilirse kısa zamanda başta rekabete daha kapalı olan çerçeve anlaşmalar olmak üzere birçok usulün yerini alma potansiyeli de bulunmaktadır. Nitekim, işleyişinin 2014 yılında sadeleştirilmesinin ardından başta Birleşik Krallık, Danimarka, Norveç, İtalya gibi ülkelerde sadece birkaç yıl içinde uygulamada katettiği kullanım düzeyi de bunun bir kanıtıdır. Bu bağlamda Mayıs 2017 itibariyle AB ihale ilanlarının elektronik olarak yayımlandığı Tenders Electronic Daily'de (TED) DAS’a ilişkin eşik değerin üstünde 242 ilan bulunduğu tespit edilmiştir. Bahsekonu ilanlardan DAS’ın en çok sosyal bakım (social care) hizmetleri (72 milyon $\mathfrak{E}$ ), okul servis hizmetleri dahil yolcu taşıma hizmetleri (93 milyon $\mathfrak{E}$ ), eğitim hizmetleri (38 milyon $\mathfrak{E}$ ) ve yapım işi ihaleleri alanında (79 milyon $\mathfrak{E}$ ) gerçekleştirildiği belirlenmiştir. ${ }^{124}$ Yine TED çerçevesinde yapılan bu incelemede, kamu alımlarında DAS kapsamında ağırlıklı olarak (sosyal bakım hizmetleri, yolcu taşımacılık hizmetleri, eğitim hizmetleri, yapım işi ihaleleri) olmak üzere 30 kategoride alım yapıldığı belirlenmiştir. ${ }^{125}$

Türk Kamu Alım Mevzuatı’nda DAS’a ilişkin 2008 yılında gerçekleştirilen düzenlemelerde 2004 yılında düzenlenen Eski AB Klasik Kamu Alım Direktifi ve Eski AB Sektörler Direktifi hükümlerinin esas alındığı ve sadece mal alımları alanıyla sınırlandırıldığı görülmektedir. Diğer taraftan, Türk Kamu Alım Mevzuatı’na 2014 yılında düzenlenen

124- Local Government Association, "A Guide to Dynamic Purchasing Systems within the Public Sector", 2017,https://www.local.gov.uk/sites/default/files/documents/4\%2030\%20DPS\%20Guidance_04_Web.pdf, (20.11.2018), s.8.

125- İbid., s.10. 
Yeni AB Klasik Kamu Alım Direktifi ve Yeni AB Sektörler Direktifi ile getirilen değişiklikler henüz aktarılmamıştır. Bununla birlikte 3 Ağustos 2018 tarihinde yayınlanan T.C. Cumhurbaşkanlığı’nın “100 Günlük İcraat Programı” kapsamına e-ihalenin yaygınlaştırılarak ihale süreçlerinde bürokrasinin azaltılması, zaman ve kaynak tasarrufu yapılarak maliyetlerin düşürülmesi ${ }^{126}$ hedefine yer verilmiş olması sözkonusu çalışmaların hızlandırılmasına neden olmuştur. Bu bağlamda Dinamik Alım Sistemi’nin mal alımı ihalelerinden başlanılarak uygulanabilmesi için Aralık 2019 tarihi hedeflenmiş olup ${ }^{127}$ sözkonusu hedef doğrultusunda Kamu İhale Kurumu bünyesinde mevzuat ve teknik çalışmalar devam etmektedir.

Diğer taraftan kamu alımlarının Gümrük Birliği kapsamına genişletilmesinin de düşünüldügü günümüzde Türk Kamu Alım Mevzuatı’nın, AB kamu alım düzenlemelerine uyumu daha da önem kazanmıştır. Sözkonusu nedenlerle, DAS çerçevesinde Yeni AB Klasik Kamu Alım Direktifi ve Yeni AB Sektörler Direktifi’ndeki değişikliklerin Türk Kamu Alım Mevzuatı'na aktarılması ve bu sayede uygulamanın kolaylaştırılması, seçilecek sektörlerde pilot uygulamalar gerçekleştirilmesi ve eğitimler düzenlenerek müteşebbislere DAS’ın uygulamasının öğretilmesi, kamu alımlarının dijitalleştirilerek elektronik ortama aktarılması çabalarına bir halka daha ekleyecek son derece önemli bir gelişme teşkil edecektir.

126- Türkiye Cumhuriyeti Cumhurbaşkanlığı, “100 Günlük İcraat Programı”, (3.8.2018), https://www.tccb.gov. tr/assets/dosya/100_GUNLUK_ICRAAT_PROGRAMI.pdf, (4.9.2019), s.18.

127- TRT HABER, "Kamu e-ihalelerinde parasal limit kalkıyor”, s.2. 


\section{KAYNAKÇA}

- Acquistinretepa. Dynamic Purchasing System. https://www.acquistinretepa.it/opencms/opencms/menu_livello_I/header/Inglese/TOOLS/Dynamic_Purchasing_System.html, (Erişim Tarihi: 21.11.2018).

- Acquistinretepa. Program: Stakeholders. https://www.acquistinretepa.it/opencms/opencms/program_eng. html, (Erişim Tarihi: 17.11.2018).

- Acquistinretepa. How it Works: Our History. https://www.acquistinretepa.it/opencms/opencms/program_ how_itWorks.html, (Erişim Tarihi: 17.11.2018).

- Acquistinretepa. Purchasing Tools Avaliable. https://www.acquistinretepa.it/opencms/opencms/program_eng. html , (Erişim Tarihi: 17.11.2018).

- Acquistinretepa. Figures. https://www.acquistinretepa.it/opencms/opencms/english/English_figures.html, (Erişim Tarihi: 20.11.2018).

- Albano L. G. (2015). The Role of Consip S.p.A in the Italian Centralized Public e-Procurement System. https:// www.kozbeszerzes.hu/data/filer_public/7d/36/7d365d0c-8ded-486c-8636-9addff996334/en_gian_luigi_ albano_centralization_italy_consip_11nov2015.pdf, (Erişim Tarihi: 17.11.2018).

- Bovis H. C. (2013). EU Public Procurement Law (2. Baskı). Cheltenham: Elgar European Law Yayınları.

- Corsi M. (2006). E-procurement Overview. https://www.oecd.org/mena/governance/36238198.pdf, (Erişim Tarihi: 12.12.2018).

-Crown Commercial Service. The Public Contracts Regulations 2015: Dynamic Purchasing System. http://www. lpp.nhs.uk/media/91686/Guidance_on_Dynamic_Purchasing_System.pdf, (Erişim Tarihi: 20.11.2018).

-Crown Commercial Service. About Us. https://www.crowncommercial.gov.uk/s/about-ccs, (Erişim Tarihi: 18.11.2018).

-Demirci D. (2014). İhale Sürecinin Elektronik Ortama Aktarılması ve Ülke Uygulamaları. (Yayınlanmamıș Uzmanlık Tezi). Kamu İhale Kurumu, Ankara.

-Demirci D. (2018). Elektronik İhalede Yeni Bir Adım Beyan Usulü. Kamu İhale Dünyası, 1 (3), 26-33.

-Edwards L. (2016). The Evidence Behind Using DPS in Procurement. https://www.procurious.com/procurement-news/evidence-using-dps-procurement, (Erişim Tarihi: 20.11.2018).

-Elektronik Kamu Alımları Platformu (EKAP) (2019). Registration of Foreign Natural and Legal Persons on Electronic Public Procurement Platform (EKAP). https://ekap.kik.gov.tr/ekap/DuyuruDetay.aspx?duyuruI-

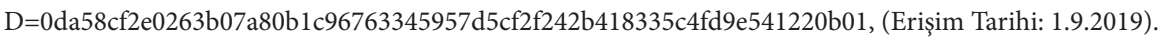

-European Commission. Public Procurement. https://ec.europa.eu/growth/single-market/public-procurement_ en, (Erişim Tarihi: 15.11.2018).

-European Commission. Legal Rules and Implementation. https://ec.europa.eu/growth/single-market/public-procurement/rules-implementation_en, (Erişim Tarihi: 15.11.2018).

-European Commission. E-procurement. https://ec.europa.eu/growth/single-market/public-procurement/e-procurement_en, (Erişim Tarihi: 15.11.2018). 
-GOV.UK. Public Procurement Policy. https://www.gov.uk/guidance/public-sector-procurement-policy\#procurement-policy-notes, (Erişim Tarihi: 16.11.2018).

-GOV.UK (2015). The Public Contract Regulations 2015. http://www.legislation.gov.uk/uksi/2015/102/pdfs/ uksi_20150102_en.pdf, (Erişim Tarihi: 20.11.2018).

- Hürriyet (2018). E-ihaleyle 50 milyon liralık tasarrufun yolu açılacak. http://www.hurriyet.com.tr/ekonomi/e-ihaleyle-50-milyon-liralik-tasarrufun-yolu-acilacak-40921914, (Erişim Tarihi: 1.9.2019).

-Local Government Association (2017). A Guide to Dynamic Purchasing Systems within the Public Sector. https://www.local.gov.uk/sites/default/files/documents/4\%2030\%20DPS\%20Guidance_04_Web.pdf, (Erişim Tarihi: 20.11.2018).

-Mastrogregori L. (2014). The Dynamic Purchasing Systems: Consip's Implementation. https://www.oecd. org/governance/procurement/toolbox/search/Italy-Dynamic-Purchasing-Systems.pdf, (Erişim Tarihi: 20.11.2018)

-Milliyet (2018). İhalelerde Elektronik Eksiltme Yapılabilecek. http://www.milliyet.com.tr/ekonomi/ihalelerde-elektronik-eksiltme-yapilabilecek-2691294, (Erişim Tarihi: 2.9.2019).

-Official Journal of the European Union (2004). 2004/17/AT sayıl AP ve Konsey Direktifi. https://eur-lex.europa. eu/legal-content/EN/TXT/PDF/?uri=CELEX:32004L0017\&from=EN, (Erişim Tarihi: 21.12.2018).

-Official Journal of the European Union (2004). 2004/18/AT sayıl AP ve Konsey Direktifi. https://eur-lex.europa. eu/LexUriServ/LexUriServ.do?uri=OJ:L:2004:134:0114:0240:en:PDF, (Erişim Tarihi: 21.12.2018).

-Official Journal of the European Union (2014). 2014/24/AB sayıl AP ve Konsey Direktifi. https://eur-lex. europa.eu/legal-content/EN/TXT/PDF/?uri=CELEX:02014L0024-20180101\&from=EN, (Erişim Tarihi: 20.11.2018).

-Official Journal of the European Union (2014). 2014/25/AB sayılı AP ve Konsey Direktifi. https://eur-lex. europa.eu/legal-content/EN/TXT/PDF/?uri=CELEX:02014L0025-20180101\&from=EN, (Erişim Tarihi: 20.11.2018).

- Özdemir E. (2018). Çerçeve Anlaşma İhaleleri. Kamu İhale Dünyası, 11(3), 2018, 33-45.

- Procurement Journey. Dynamic Purchasing Systems (DPS). https://www.procurementjourney.scot/dynamic-purchasing-systems-dps, (Erişim Tarihi: 20.11.2018).

- Procurement Journey. Scottish Procurement Suppliers Guide:Digital Services- Dynamic Purchasing System. https://www.procurementjourney.scot/sites/default/files/documents_library/Digital\%20Services\%20-\%20 DPS\%20-\%20Supplier\%27s\%20Guide.pdf, (Erişim Tarihi: 20.11.2018).

- Public Contracts Scotland. About Us. https://www.publiccontractsscotland.gov.uk/aboutus/aboutus_main. aspx, (Erişim Tarihi: 18.11.2018).

- Public Contracts Scotland. Search for Notices. https://www.publiccontractsscotland.gov.uk/search/search_mainpage.aspx, (Erişim Tarihi: 17.11.2018).

-Smith P. (2018). Public Procurement Workshop: Dynamic Purchasing Systems. https://www.slideshare.net/ SIGMA2013/presentation-sigma-public-procurement-workshop-dynamic-purchasing-systems-turkey-10-april-2018, ( Erişim Tarihi: 12.12.2018). 
- Smith S. (2016). Dynamic Purchasing System: Planning. http://www.localgovernmentlawyer.co.uk/index. php?option $=$ com_content $\&$ view $=$ article $\&$ id $=27168 \% 3$ Adynamic-purchasing-systems-planning $\&$ cati$\mathrm{d}=53 \&$ Itemid $=21$, (Erişim Tarihi: 15.11 .2018$)$.

-Smith S. (2016). Operating a Dynamic Purchasing System. https://www.publiclawtoday.co.uk/procurement-and-contracts/354-procurement-features/30621-operating-a-dynamic-purchasing-system, (Erişim Tarihi: 17.11.2018).

- Türkiye Cumhuriyeti Cumhurbaşkanlığı (2018).100 Günlük İcraat Programı. https://www.tccb.gov.tr/assets/ dosya/100_GUNLUK_ICRAAT_PROGRAMI.pdf, (Erişim Tarihi: 4.9.2019).

- T.C. Cumhurbaşkanlığı Resmi Gazete (2019). Elektronik İhale Yönetmeliği’nde Değişiklik Yapılmasına Dair Yönetmelik. http://www.resmigazete.gov.tr/eskiler/2019/06/20190613-5.htm, (Erişim Tarihi: 1.9.2019).

- T.C. Kamu İhale Kurumu (2004). 2003 Yll Faaliyet Raporu. http://www2.ihale.gov.tr/Duyurular2012/2003_ yili_faaliyet_raporu.pdf, (Erişim Tarihi: 1.9.2019).

- T.C. Kamu İhale Kurumu (2005). 2004 Yilı Faaliyet Raporu. http://www2.ihale.gov.tr/Duyurular2012/2004_ yili_faaliyet_raporu.pdf, (Erişim Tarihi: 1.9.2019).

- T.C. Kamu İhale Kurumu (2006). 2005 Yil Faaliyet Raporu. http://www2.ihale.gov.tr/arge/2005_yili_Faaliyet_Raporu.pdf, (Erişim Tarihi: 1.9.2019).

- T.C. Kamu İhale Kurumu (2011). 2010 Yilı Faaliyet Raporu. http://www2.ihale.gov.tr/kik/Belgeler/2010\%20 Y\%C4\%B11\%C4\%B1\%20Faaliyet\%20Raporu.pdf, (Erişim Tarihi: 2.9.2019).

- T.C. Kamu İhale Kurumu (2019).1 Haziran 2019 İtibariyle İhale Dokümanlarının İdarelerden Satın Alınması Uygulaması Kaldırılıyor. https://www.ihale.gov.tr/Duyuru/306/1_haziran_2019_itibariyle_ihale_dokumanlarinin_idarelerden_satin_alinmasi_uygulamasi_kaldiriliyor.html, (Erişim Tarihi: 1.9.2019).

- T.C. Resmi Gazete (2002). Kamu İhale Kanunu. http://www.resmigazete.gov.tr/main.aspx?home=http:// www.resmigazete.gov.tr/eskiler/2002/01/20020122.htm\&main=http://www.resmigazete.gov.tr/eskiler/2002/01/20020122.htm, (Erişim Tarihi: 21.11.2018).

- T.C. Resmi Gazete (2008). Kamu İhale Kanunu ve Kamu İhale Sözleşmeleri Kanununda Değişiklik Yapılmasina Dair Kanun. http://www.resmigazete.gov.tr/main.aspx?home=http://www.resmigazete.gov.tr/eskiler/2008/12/20081205.htm\&main=http://www.resmigazete.gov.tr/eskiler/2008/12/20081205.htm , (Erişim Tarihi: 21.11.2018).

- T.C. Resmi Gazete (2011). Elektronik İhale Uygulama Yönetmeliği. http://www.resmigazete.gov.tr/eskiler/2011/02/20110225-17.htm, (Erişim Tarihi: 1.9.2019).

-The Organization for Economic Cooperation and Development (OECD) (2016). Division of Contracts into Lots. http://www.sigmaweb.org/publications/Public-Procurement-Policy-Brief-36-200117.pdf, (Erişim Tarihi: 15.11.2018).

-TRT HABER (2018). Kamu e-ihalelerinde parasal limit kalkıyor. https://www.trthaber.com/haber/turkiye/kamu-e-ihalelerinde-parasal-limit-kalkiyor-396615.html, (Erişim Tarihi: 2.9.2019).

-YPO. About YPO. https://www.ypo.co.uk/about, (Erişim Tarihi: 19.11.2018).

-YPO. History of YPO. https://www.ypo.co.uk/about/history, (Erişim Tarihi: 19.11.2018). 